\title{
Basic Approaches to Legal Security Understanding and Its Provision at an International Level
}

\author{
Galina S. Belyaeva ${ }^{1}$, Ekaterina V. Butova ${ }^{1}$, Yuliya A. Krylova ${ }^{1}$, Viktoriya S. Kirilenko ${ }^{2}$ \& Oksana V. Shmalij ${ }^{3}$ \\ ${ }^{1}$ Belgorod State University, Russia, 85 Pobeda Street, Belgorod, Russia \\ ${ }^{2}$ The Institute of service sector and entrepreneurship (branch) of DSTU in Shakhty, 147 Shevchenko street, \\ Shakhty, Rostov oblast, Russia \\ ${ }^{3}$ South-Russian Institute-branch of Ranepa, 70/54Pushkin st., Rostov-on-don, Russia \\ Correspondence: Galina S. Belyaeva, Belgorod State University, Russia, 85 Pobeda Street, Belgorod, 308015, \\ Russia. E-mail: belvp46@mail.ru
}

Received: June 19, 2017

doi:10.5539/jpl.v10n4p192
Accepted: July 18, $2017 \quad$ Online Published: August 30, 2017

URL: https://doi.org/10.5539/jpl.v10n4p192

\begin{abstract}
This article contains an integrated interdisciplinary approach to the study of legal security and its provision at an international level. The study is aimed at the development of conceptual approaches to the understanding of legal security in a general social sense and the ways of its provision at an international level. The evolution of approaches to the determination of an individual, society and a state legal security is considered, and attention is drawn to the need of legal component strengthening concerning the process of national and international security provision. The main determinants of international activity for legal security provision are established and systematized.
\end{abstract}

Keywords: security, legal security, international security, concept, security system, integrated character, systemic character

\section{Introduction}

Modern doctrinal general theoretical approaches to the definition of legal security are distinguished by some uncertainty and underestimation (or ignoring) of the main methodological aspects concerning a concept (a strategy, a single program) development for national and international security, which, in its turn, excludes a single algorithm of development, formulation, adoption and implementation of strategic directions to ensure state, public and personal safety within individual states as well as international security within a global scale.

These negative trends lead to the fact that during the law-making process, the development of official state (and interstate) documents of a strategic (a conceptual) nature the rules and principles of declarative nature are set often at the cost of precise and uniform formulation of the main goals, objects (spheres), means, mechanisms and methods of security provision.

From our point of view, in order to systematize the conceptual legal approaches to the understanding of security, it is necessary to address to the identification of this concept legal content first of all.

We believe that regardless of what is meant by security, a strategic goal, a scientific program, an individual, state and society status, etc., the issues of personal security, national security, international security and global security are largely disconnected, as they are related to completely different spheres. There are also the points of view concerning the absence of an individual legal security independent concept and the "absorption" of this phenomenon by other social spheres. So, for example, George Nef, considering human security, distinguishes the following constituent elements in it: physical, economic, social, political, legal and cultural one; at that, according to the scholar, legal security makes the part of political security and embodies only the possibility of individual and collective access to justice and the protection from abuse (Nef, 1999). Such a narrow approach to security problems is difficult to recognize as fully just and justified.

Summarizing all mentioned above, it seems necessary to identify some conceptual approaches here to the definition of security in a general social sense and its provision at an international level. 


\section{Methodology}

Various general scientific methods and the methods of logical cognition are used in the work: analysis and synthesis, abstraction, modeling, system-structural, functional and formal-logical approaches. The methodological basis of the study should also include a system-holistic approach to legal phenomena, allowing them to be viewed as the systems that have not only internal but also external links; a comparative legal approach that involves the exchange of information at the level of the world legal science and the search for new parameters to compare the phenomena of legal reality from different countries.

\section{Discussion and Results}

Let's consider the basic approaches, from our point of view, to the definition of national security. The first approach is an official one, in which security is defined as the protection of interests (including national ones) from threats. In the original sense, this is the protection of the territory from external threats, carried out by military means in the conditions of an anarchic state system, which, according to the postulates of structural realism (Waltz, 2000), is characterized by a constant rivalry for security. Then the transformation of security understanding caused the attention of scientists to so-called "internal" threats (the state of the environment, terrorism, refugees, crime, etc.), and the threats not only to states, but also to individuals and their groups (Paris, 2001).

The second approach to the definition of security (system-philosophical one) emphasizes the need to preserve integrity, stability, normal functioning and a sustainable development of a system (a country, a state, a society as a social system). This concept is reflected in many international documents, the consideration of which will be presented further, as well as in the National Security Strategy of RF until 2020 (The decree of Russian Federation President No. 683, 2015).

Moreover, this understanding of security is reflected in other sciences. Thus, the American scholar J. Kirchner of Cornell University regards "national vitality" as an important aspect of a state in respect of social-economic relations, which is interpreted as the ability of society to solve existing problems purposefully (Krishner, 1988).

The third approach to the notion of security, let's call it axiological one, regards security as the protection of values belonging to a subject (a country, society, a collective, a person) and from the damage significant for him. This perception of security is characteristic of Western European political consciousness, where a social phenomenon under consideration, along with democracy and human rights, became an integral part of the liberal worldview a long time ago.

In particular, Hegel regarded a state as "a self-conscious moral substance". In his opinion, the destruction of public morality through the undermining of family foundations, the moral degradation of an individual, the loss of religious feelings, etc., leads to the disintegration of the spiritual foundations that ensure the stability of a state, both before external threats and before internal contradictions.

The English Bill of Rights of 1689, in which security is linked to the unity of the world and the tranquility of people and the welfare of a state may also serve as an example (Bill of Rights, 2017). A similar provision is contained in the American Declaration of Independence of 1776, where the creation of security guarantees is proclaimed as the right and the duty of the people, and the provision of security and happiness to people is the task of state power (The Declaration of Independence, 2017).

Despite the recognition of the justice of the main provisions concerning all of the above-mentioned approaches, let's draw attention to the need of "legal security" phenomenon legal component strengthening.

R. Jackson's opinion, according to which legal security is a "civil condition created and supported by a state using the rule of law", is considered as fair in the light of the comment mentioned above (Jackson, 2003). In general, the terms "legal security" and "legal certainty" in English legal literature are used as the synonyms and designate "the predictability of legal decisions" (Hegel, 1977).

A systematic approach to the definition of legal security is contained in G. Kelsen's work "Collective security in international law" which notes the fact that there are two main values of the considered concept in science. The first one is related to the international security of a state, which is divided into political and legal (juridical) security, and is defined as "the state in which a state observes the objective law without fear that its rights as a subject of international law will be violated without compensation" (Peczenik, 2008). The second meaning of the legal security notion used in English literature derives from the German legal science (from the German word Rechtssicherheit) and denotes the principle according to which the legal and administrative acts of a state must be conditioned by a preliminary established legal norm (Kelsen, 2001). 
Thus, the notion of "juridical (legal) security" in its most general form is a multifaceted phenomenon that, in our opinion, is necessary to consider:

- In space: as the part of an international security concerning the security within the borders of a certain state (its state borders);

- In relation to the national interests of a particular state population: as a state of a person and society vital interest protection from internal and external threats;

- Regarding military threats: as a country situation, in which it is not threatened by war or other encroachments on sovereign development;

- In relation to a state sovereignty: as a state condition, under which its integrity and the opportunity to be an independent subject of international relations are ensured.

The Charter of the United Nations should be recognized as the main international document in the sphere of international security. An attempt was made in this document to create a mechanism for "international peace and security provision" (The Charter of the United Nations, 2017).

In particular, the UN Charter defines the basic principles of international security law, namely, the principles of peaceful settlement of disputes and the non-use of force or a threat of force use for the implementation of which States are obliged to provide the United Nations with all possible assistance in its actions and refrain from assistance provision to any state against which it undertakes the actions of a preventive or a compulsory nature. These provisions are also applied to the states that are not the members of the United Nations, calling for the latter to act in accordance with these principles to the extent necessary for the maintaining of international peace and security (clause 6 , article 2 of the Charter).

The foundations of international security also develop other principles of international law. So, according to Art. 3 and 28 of the Universal Declaration of Human Rights, the respect for human rights, democracy are of paramount importance to prevent the threat to peace. Everyone has the right to life, and a state and the international community as a whole must ensure an international order in which this right can be exercised (Universal Declaration of Human Rights, 2017).

From this position follows the human right to peace, which is connected with the right to the peace to people and a state. In 1984 the General Assembly formulated the "sacred right of peoples to peace", the guarantee of which is a fundamental obligation of states within the Declaration of people right to peace (Declaration on the Right of Peoples to Peace, 2017).

The principle of international obligations conscientious fulfillment is of particular importance. Thus, Article 1, paragraph 1 of the UN Charter states the task "to maintain an international peace and security and to take effective collective measures for this to prevent and eliminate any threats to peace and suppress the acts of aggression or other violations of peace and to conduct the adjustment or the settlement of international disputes or situations that could lead to a breach of peace by peaceful means, in accordance with the principles of justice and international law" (The Charter of the United Nations, 2017).

It should also be noted that in a number of documents adopted by authoritative international organizations during 1980-IEs - 1990-IEs, - from the "Brandt Commission" (Brandt, 1968) to the "Commission of the South" and the participants in the Stockholm initiative (Sohn, 1973) the need was admitted for a broader reconsideration of the ways to ensure security, the shift of the emphasis from disarmament to social-economic and other non-military sources of instability elimination.

At an international conference on the relationship between disarmament and development, held under the auspices of the United Nations in 1987, and at the meeting of experts on non-military aspects of security held in Tashkent in 1990, an expanded definition of security was adopted, including the absence of external political pressure and economic coercion, the opportunity for states to "pursue national development and progress freely, as well as the meeting of basic needs and human rights" (Kalaydzhyan, 2009).

It is indisputable that the United Nations should remain the center for the regulation of international relations and world politics coordination in the 21 st century, which proved its non-alternative nature and is endowed with a unique legitimacy. All world powers must support the efforts, strengthening its central and coordinating role, which implies: a steady observance of the purposes and principles recorded in the UN Charter; the rational reform of the United Nations for its systematic adaptation to the changing political and economic realities in the world; A further increase in the effectiveness of the UN Security Council activities, which has the primary responsibility for the maintenance of international peace and security, making this body more representative in the process of 
reforming while ensuring due efficiency in its work. Any decisions on additional seats creation in the UN Security Council should be made on the basis of the broadest consensus of the UN member states. The status of the five permanent members of the UN Security Council should be preserved.

It is necessary to take the following actions to achieve these goals. First of all, it is necessary to organize the work on the systemic strengthening of international security legal foundations, since only universally recognized norms and principles of international law can determine the "game rules" in relations between states. In its turn, the development of the habit among international law subjects to correlate their actions with international norms will help to reduce the "hard" force factor, to establish a collective way of actions in order to prevent world chaos that threatens international law and order.

Secondly, it is necessary to develop a polycentric international system based on the reforms of the leading international institutions, the strengthening of multilateral diplomacy and the prevention of single dominance in any sphere.

Thirdly, it is proposed to approve universal diplomatic methods resolving crisis situations, based not on the isolation of so-called "problem" states (wherever they are in the world), but on their participation in an international dialogue.

\section{Conclusions}

Thus, in the most general form legal security should be understood as a state of protection concerning an individual, society and a state from a wide range of internal and external threats, which ensures the implementation of constitutional citizen rights and freedoms, a decent quality and standard of their living, sovereignty, independence, state and territorial integrity and a sustainable social-economic development of a state. Thus, security has not only (and not so much) protective content (protection from threats) in a legal sense, but also ensures an optimal state and an effective operation of social institutions, sufficient for the development of an individual, society and a state. The provision of national and international security as the main goal and content of state activity, determines the main directions of its functioning at an international level and within the domestic political sphere.

\section{References}

Bill of Rights - "An Act declaring the Rights and Liberties of the Subject and Settling the Succession of the Crown". Date Views 28.04.2017. http://www.legislation.gov.uk/aep/WillandMarSess2/1/2/contents

Brandt, W. (1968). Friedenspolitik in Frankfurt. M., S. 58.

Declaration on the Right of Peoples to Peace. Date Views 15.05.2017. http://research.un.org/en/docs/ga/quick/regular/39

Hegel, G. V. F. (1977). Philosophy of law. Encyclopedia of philosophical sciences.

Jackson, R. (2003). The global covenant: human conduct in a world of states. Oxford University Press. https://doi.org/10.1093/0199262012.001.0001

Kalaydzhyan, A. A. (2009). National Security of Russia: historical, legal and theoretical aspects. Proceedings of the Russian state pedagogical university named after A.I. Herzen. pp. 150-152.

Kelsen, H. (2001). Collective security under international law. Washington D.C. P. 3-4.

Kirshner, J. (1988). Political Economy in Security Studies after the Cold War. Review of International Political Economy, 5(1), 64-91. https://doi.org/10.1080/096922998347651

Nef, J. (1999). Human security and mutual vulnerability: the global political economy of development and underdevelopment. Ottawa. P. 25.

Paris, R. (2001). Human security: Paradigm Shift or Hot Air? International Security, 26(2), 97. https://doi.org/10.1162/016228801753191141

Peczenik, A. (2008). On Law and Reason. Springer Science + Business Media B.V. P. 24.

Sohn, L. B. (1973). The Stockholm Declaration on the Human Environment. The Harvard International Law Journal, 14, 423-515.

The Charter of the United Nations. Date Views. (2017). Retrieved from http://www.un.org/en/charter-united-nations/index.html

The Declaration of Independence. Date Views. (2017). Retrieved from http://www.ushistory.org/DECLARATION/document/ 
The decree of Russian Federation President No. 683 "On Russian Federation National Security Strategy" issued on December 31, 2015. http://www.kremlin.ru/acts/bank/40391

Universal Declaration of Human Rights. Date Views. (2017). Retrieved from http://www.refworld.org.ru/docid/47a080da2.html

Waltz, K. N. (2000). Structural Realism after the Cold War. International Security, 25(1), 5-41. https://doi.org/10.1162/016228800560372

\section{Copyrights}

Copyright for this article is retained by the author(s), with first publication rights granted to the journal.

This is an open-access article distributed under the terms and conditions of the Creative Commons Attribution license (http://creativecommons.org/licenses/by/4.0/). 